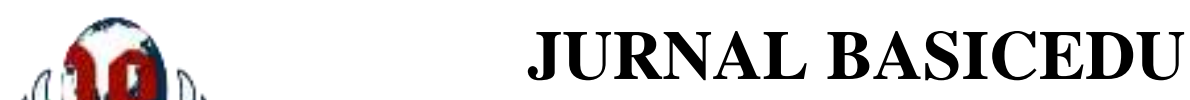

Volume 6 Nomor 1 Tahun 2022 Halaman 894 - 901

Research \& Learning in Elementary Education https://jbasic.org/index.php/basicedu

\title{
Pembentukan Karakter Religius Peserta Didik Melalui Kegiatan Ekstrakurikuler di Madrasah Ibtidaiyah
}

\author{
Khairunnisa Lubis
}

Universitas Islam Negeri Sumatera Utara, Indonesia

E-mail: nisalbsx9@gmail.com

\begin{abstract}
Abstrak
Penelitian ini bertujuan untuk membentuk karakter religius siswa melalui kegiatan ekstrakurikuler, faktor pendukung dalam melaksanakan penelitian ini adalah guru, orang tua, dan pelatih ekstrakurikuler di Mis Nurul Iman. Metode penelitian menggunakan pendekatan kualitatif untuk menjabarkan hasil temuan dalam penelitian. Jenis penelitian yang digunakan adalah penelitian deskriptif dengan pendekatan kualitatif. Penelitian ini dilakukan di Mis Nurul Iman, Tanjung Morawa, Kab. Deli Serdang. Hasil penelitian menunjukkan bahwa Mis Nurul Iman telah menerapkan pembentukan karakter disiplin siswa berbasis religius. Melalui kegiatan ekstrakurikuler tersebut siswa memperoleh kesempatan untuk mengetahui dasar-dasar karakter religius dan mengimplementasikannya secara nyata untuk membentuk kesiapan sosial oleh siswa di Mis Nurul Iman. Sekolah telah menerapkan berbagai strategi dalam pembentukan karakter religius siswa di Mis Nurul Iman, serta kegiatan ekstrakurikuler Da'I ini dapat membantu pembentukan karakter religius siswa dengan baik dan cepat. Kegiatan ekstrakurikuler di Mis Nurul Iman terbilang berhasil dalam membentuk karakter religius peserta didik karena Mis Nurul Iman menerapkan program-program yang sesuai dengan norma-norma agama Islam.
\end{abstract}

Kata Kunci: karakter, religius

\begin{abstract}
This study aims to shape the religious character of students through extracurricular activities, the supporting factors in carrying out this research are teachers, parents, and extracurricular trainers at Mis Nurul Iman. The research method uses a qualitative approach to describe the findings in the study. The type of research used is descriptive research with a qualitative approach. This research was conducted in Mis Nurul Iman, Tanjung Morawa, Kab. Deli Serdang. The results of the study indicate that Mis Nurul Iman has implemented the formation of religious-based student discipline character. Through these extracurricular activities students have the opportunity to know the basics of religious character and implement them in real terms to form social readiness by students at Mis Nurul Iman. The school has implemented various strategies in the formation of the religious character of students at Mis Nurul Iman, and this Da'I extracurricular activity can help the formation of students' religious character well and quickly. Extracurricular activities at Mis Nurul Iman are quite successful in shaping the religious character of students because Mis Nurul Iman implements programs that are in accordance with Islamic religious norms.
\end{abstract}

Keywords: character, religious

Copyright (c) 2022 Khairunnisa Lubis

$\triangle$ Corresponding author :

Email : nisalbsx9@gmail.com

ISSN 2580-3735 (Media Cetak)

DOI $:$ https://doi.org/10.31004/basicedu.v6i1.2054

ISSN 2580-1147 (Media Online) 


\section{PENDAHULUAN}

Pendidikan karakter merupakan mata pelajaran yang penting untuk dikaji dan didiskusikan saat ini. Penyakit kronis anak-anak bangsa dan degradasi moral yang meluas adalah alasan utama sifat kritis dari pembangunan karakter, khususnya karakter religius. Pendidikan karakter diperlukan untuk membantu siswa menginternalisasi prinsip-prinsip karakter. Pendidikan karakter religius diperlukan karena banyak perilaku siswa yang tidak sesuai dengan nilai-nilai agama. Penduduk Indonesia yang terbiasa dengan kesopanan dalam berperilaku, kontemplasi dalam pemecahan masalah, pluralitas dalam kearifan lokal, perilaku toleran, dan gotong royong, mulai condong ke arah hegemoni kelompok dan keegoisan individu. (2013) (Setiawan).

Dalam hal ini, ada banyak metode pendidikan yang membahas pendidikan karakter. Siswa yang berilmu, pandai, dan kreatif akan menderita jika aspek keagamaan siswa tersebut diremehkan. Oleh karena itu, harus ada keseimbangan antara pendidikan sains dan pendidikan karakter agama. Mereka membutuhkan karakter religius untuk menghadapi perubahan zaman dan kemerosotan moral; oleh karena itu, siswa dituntut untuk menunjukkan perilaku dan kepribadian yang sesuai dengan hukum atau prinsip agama (Hambali \& Yulianti, 2018). Pendidikan karakter tidak hanya bertanggung jawab untuk menanamkan nilai-nilai karakter; itu juga harus diterapkan dalam kehidupan sehari-hari, agar siswa lebih cepat dan mudah menyadari hakikat kritis pendidikan karakter (Fahlevi et al., 2021).

Lingkungan di mana anak-anak tumbuh dan berkembang memiliki dampak yang signifikan terhadap karakter mereka. Meskipun aspek bawaan dapat berpengaruh pada karakter, persentasenya sangat kecil. Anak muda yang tumbuh dan berkembang dalam lingkungan yang bermoral secara alami akan mengembangkan akhlak yang prima, begitu pula sebaliknya (Purandina \& Winaya, 2020).

Banyak anak zaman sekarang yang kurang memiliki karakter religius dalam kehidupan sehari-hari. Misalnya, kurangnya toleransi, masih banyak siswa yang masih awam dalam membaca dan menulis $\mathrm{Al}$ Qur'an, tidak yakin bagaimana memulai dan melanjutkan belajar shalat, dan lain sebagainya. Pengembangan metode pendidikan karakter ini memenuhi syarat untuk memotivasi siswa dalam mengimplementasikan citacita agama dalam kehidupan sehari-hari. Banyak orang tua dan guru yang lalai dalam memberikan pendidikan karakter religius dan mendorong siswa untuk mengikuti kegiatan ekstrakurikuler yang disponsori sekolah. Dengan demikian, dengan pengembangan karakter melalui kegiatan ekstrakurikuler, aturan atau cita-cita agama niscaya dapat diterapkan.

Pengembangan karakter religius melalui kegiatan ekstrakurikuler memiliki peran penting dalam mengembangkan karakter siswa. Untuk mendemonstrasikan, itu harus dilakukan dengan cara yang menarik. Karena siswa, khususnya yang masih duduk di bangku sekolah dasar, lebih cenderung belajar sambil bermain, maka kita harus dapat menyediakan kegiatan yang menarik yang mendorong siswa untuk berpartisipasi dalam kegiatan ekstrakurikuler yang mempromosikan pengembangan karakter Kristen. Kegiatan ekstrakurikuler da'i merupakan salah satu kegiatan yang membantu pembentukan karakter religius di sekolah.

Yayasan Pendidikan Nurul Iman didirikan pada hari Kamis, 13 Juni 1991. Yayasan ini didirikan oleh notaris Syahril Sofyan, SH di alamat Jalan Mayjen Sutoyo Siswomiharjo 28 Medan dengan nomor akta 34. Yayasan ini didedikasikan untuk pendidikan agama dan beroperasi di luar Desa Limau Manis di Kecamatan Tanjung Morawa Kabupaten Deli Serdang. Salah satu operasional yayasan pendidikan tersebut adalah Diniyah Awaliyah Adrasa (MDA) yang didirikan pada tanggal 1 Juli 1990 di bawah kepemimpinan Al-Ustadz Drs. H. Syarif Hardi. Tujuan utama kegiatan komersial ini adalah menjadikan MDA Mis Nurul Iman sebagai center of excellence dalam penyelenggaraan pendidikan bagi umat Islam yang beriman, bertaqwa, berakhlak mulia, dan berwawasan global.

Menurut Hambali \& Yulianti (2018), pendidikan karakter agama melalui kegiatan ekstrakurikuler di sekolah memiliki dampak yang signifikan dan baik bagi perkembangan siswa dalam hal kemampuannya untuk memahami dan menerapkan keyakinan agama Islam dalam kehidupan sosialnya. Menurut Huda et al. (2021), 
strategi dan implementasi lembaga pendidikan merupakan salah satu variabel yang mempengaruhi proses pembentukan karakter religius siswa. Menurut penelitian (Hidayah et al., 2018), pendidikan karakter agama sangat penting untuk sekolah dasar sebagai sarana meletakkan dasar untuk pemahaman agama tingkat yang lebih tinggi. Menurut perspektif ini, penelitian anggota ekstrakurikuler MDA Mis Nurul Iman tentang pembentukan karakter religius cukup menarik. Tujuan dari penelitian ini adalah untuk menunjukkan bagaimana strategi Mis Nurul Iman sebagai organisasi fundamental berkontribusi pada pembentukan karakter religius pada siswa melalui kegiatan ekstrakurikuler Da'i. Pembentukan karakter religius ini dirasa perlu mengingat anak-anak sekarang yang belajar dari rumah dan tidak melakukan interaksi dengan orang lain menyebabkan anak kesulitan dalam melakukan komunikasi dengan orang lain (Muthmainnah et al., 2022).

Beberapa penelitian tersebut menunjukkan bahwa pembentukan karakter religius berpengaruh terhadap pembentukan karakter siswa secara umum dengan melalui kegiatan ekstrakurikuler Da'i. Karakter yang seperti apa dan bagaimana belum terukur dengan jelas pada beberapa penelitian tersebut. Dengan demikian perlu penelitian- penelitian lanjutan yang dapat lebih fokus mengenai karakter apa saja yang dibentuk melalui kegiatan ekstrakurikuler Da'I (Khairani \& Putra, 2021). Jika yang diutamakan adalah karakter religius, bagaimana pengaruh program kegiatan ekstrakurikuler Da'i ? Dalam hal ini peneliti mengkaji penerapan program kegiatan ekstrakurikuler Da'i di Mis Nurul Iman, dalam pembentukan karakter religius siswa. Artikel ini menguraikan pengaruh kegiatan ekstrakurikuler Da'i yang dilaksanakan di Mis Nurul Iman dalam pembentukan karakter religius siswa.

\section{METODE PENELITIAN}

Penelitian ini menggunakan pendekatan-pendekatan untuk membahas temuannya. Tempat penelitian terletak di Mis Nurul Iman Tanjung Morawa, Kabupaten Deli Serdang, Sumatera Utara. Penelitian berlangsung selama 4 bulan dan subjek penelitian terdapat 40 anggota Da'i di Mis Nurul Iman dan peserta ekstrakurikuler Da'i. Hal ini memungkinkan untuk identifikasi informan, salah satunya adalah pembina ekstrakurikuler Da'i dan empat di antaranya adalah anggota Da'i Mis Nurul Iman. Pengumpulan data penelitian dilakukan dengan metode wawancara. Wawancara dilakukan melalui Whatsapp guna menyikapi kondisi pandemi covid-19 dan tetap mematuhi protokol kesehatan. Wawancara ini dibantu oleh beberapa pihak yaitu pembina ekstrakurikuler, guru sekolah, dan kepala sekolah. Analisis data menggunakan analisis deskriptif kualitatif, teknik analisis kualitatif memungkinkan peneliti untuk menggali lebih dalam temuan penelitian untuk mendapatkan pemahaman yang lebih baik tentang tantangan dan jawaban penelitian analisis data yang dilakukan meliputi pengolahan dan interpretasi data melalui kalimat-kalimat yang berkesinambungan dan induktif. Secara umum, proses analisis data penelitian ini terdiri dari tiga langkah, yaitu reduksi data (reduksi data), penyajian data (data presentation), dan penarikan kesimpulan (verificarion).

\section{HASIL DAN PEMBAHASAN}

Pembangunan kepribadian bangsa harus diwujudkan melalui tindakan nasional dalam rangka membentengi landasan spiritual, moral, dan etika pembangunan nasional dalam upaya menjaga jati diri bangsa dan memperkokoh persatuan dan kesatuan bangsa di bawah naungan Negara Kesatuan Republik Indonesia. Republik Indonesia. Proses pembangunan karakter bangsa harus sistematis, integratif, dan berlarut-larut. Strategi pembangunan dapat diupayakan melalui sosialisasi, enkulturasi, dan internalisasi melalui berbagai institusi dengan menjelaskan keadaan lingkungan dan kebutuhan warga, serta pendekatan multidisiplin yang tidak diarahkan pada indoktrinasi. Hal tersebut sejalan dengan PMR dapat membangun nilai kepedulian. Implementasi Ekstrakurikuler melalui pembiasaan dilakukan dengan membangun nilai kejujuran pada 
program kantin kejujuran dan pembiasaan peduli lingkungan yang dapat membangun nilai kepedulian (Sari et al., 2021).

Istilah Da'i mengacu pada orang-orang yang berdakwah dalam rangka menyebarkan ajaran Islam. Menurut Umar Hasyim, Da'i berarti mengajak orang, membimbing mereka, dan membujuk mereka untuk beriman kepada agama dan ajaran Allah. Artinya, manusia dapat beriman dan mengikuti petunjuk Allah SWT. Da'i juga dianggap memiliki lebih banyak sumber daya dan kemampuan untuk memaknai pesan-pesan keagamaan bagi masyarakat sebagai panutan moral. Dalam menyikapi peristiwa keagamaan, para da'i seharusnya tidak hanya fokus pada persoalan pribadi, tetapi juga pada realitas sosial. Untuk mencapai tujuan ini, sangat penting untuk memiliki sumber daya atau sumber daya untuk pelaksanaan dakwah, khususnya da'i yang terampil, ahli, dan berkualitas baik pada tingkat pribadi maupun profesional. Mis Nurul Iman mengembangkan kegiatan ekstrakurikuler berdasarkan informasi tersebut untuk membentuk karakter da'i yang memenuhi syarat klasifikasi. Menurut kegiatan ekstrakurikuler Da'i di Mis Nurul Iman, beliau mengajar murid-muridnya tidak hanya bagaimana mensosialisasikan, mengajak, dan membimbing kehidupan agama Allah kepada manusia, tetapi juga bagaimana secara pribadi melaksanakan agama Allah secara moral dan kualitas dalam kehidupan sehari-hari (Oktari \& Kosasih, 2019).

Mempelajari Al-Qur'an sangat penting untuk kelangsungan hidup di dunia ini dan di akhirat. Al-Quran dapat diajarkan kepada anak-anak pada usia berapa pun, baik di dalam maupun di luar sekolah, seperti di masjid, di rumah, atau di taman bermain (Hakim, n.d.).

Untuk mencapai kesuksesan, modal pertama, atau modal awal, harus aktif antara sekolah dan orang tua. Tentunya sekolah sudah mengembangkan rasa kebersamaan, apalagi pergaulan. Kerjasama dengan orang tua berupa komunikasi antara guru di sekolah dengan orang tua siswa dalam hal penegakan disiplin siswa. Komunikasi langsung dengan orang tua melalui berbagai metode pertemuan terjadwal. Pertemuan tersebut dapat menjadi sarana bagi sekolah untuk berkomunikasi dengan orang tua siswa, mengevaluasi siswa secara berkala dalam rangka mempersatukan mereka, dan bersidang di akhir tahun ajaran (Perdima \& Kristiawan, 2021).

Berdasarkan hasil penelitian didapatkan hasil pendidikan karakter keagamaan di Mis Nurul Iman, sekolah memiliki kebijakan dan program yang membantu guru dalam mengarahkan anak menuju pendidikan karakter guna mengembangkan karakter yang dibutuhkan. Selain itu, organisasi Yayasan Nurul Iman melakukan pengawasan yang ketat terhadap pembentukan karakter religius siswa saat mereka terlibat dalam kegiatan yang berhubungan dengan sekolah atau kegiatan di luar sekolah. Hal ini sesuai dengan penegasan Fahlevi et al. (2021), bahwa pembinaan karakter religius berupa aspek ketertiban, penguatan keagamaan, dan karakter siswa sangat penting selama sekolah dasar untuk menciptakan kehidupan yang bahagia. Dengan demikian, anak-anak akan dapat menggunakan sains di sekolah dasar untuk menyesuaikan atau menjadi terbiasa dengan kehidupan sekolah, terutama di tingkat yang lebih tinggi, di masa depan. Hal ini sesuai dengan penegasan Rahmawati et al. (2020). bahwa pengembangan karakter dapat terjadi melalui berbagai metodologi pendidikan atau pembelajaran. Strategi tersebut dilakukan melalui pengembangan kebijakan dan pembinaan karakter dalam kegiatan sehari-hari, khususnya dalam kegiatan ekstrakurikuler dakwah. Kegiatan ekstrakurikuler dakwah secara efektif memadukan pendidikan karakter religi, yang sengaja dirancang agar kelak para santri tidak hanya memahami konsep, tetapi juga mampu menjalankan ritual atau aplikasi keagamaan dan terbiasa bertindak dengan akhlak mulia.

Melanjutkan pernyataan tersebut, Pembina Da'i menyusun strategi sekolah untuk menggunakan ekstrakurikuler dakwah untuk membentuk karakter religius siswa. Dalam ekstrakurikuler ini, Da'i dijiwai dengan prinsip-prinsip unik yang tidak hanya membentuk karakter pribadi yang religius, tetapi juga diperlukan masyarakat untuk menghasilkan pribadi yang memiliki kompetensi Da'i. Menurut pembimbing khatib, berbagai sifat yang diajarkan pada santrinya melalui kegiatan ekstrakurikuler Dakwah/Da'i, antara lain: 


\section{Kepribadian Secara Jasmani}

Seorang da'i profesional berkhotbah di antara sekelompok besar orang yang memiliki persepsi berbeda tentang seseorang. Kesehatan fisik sangat penting dalam pengertian ini. Pembina menekankan pentingnya penampilan bagi para da'i di Mis Nurul Iman, baik jasmani maupun rohani. Selain itu, instruktur menggarisbawahi perlunya seorang Da'i mengingat kesulitan mereka ketika memilih pakaian yang sesuai. Hal ini karena pakaian tersebut menyampaikan kepribadian Da'i kepada masyarakat umum. Saat berdakwah, pakaian yang dikenakan harus sesuai dengan lokasi dan konteks. Penelitian Hendra, (2018) menyebutkan bahwa kepribadian da'i akan semakin tampak profesionalime sesuai dengan penambilannya.

\section{Kepibadian Secara Rohani}

Sikap dan perilaku da'i sangat menentukan keberhasilan dakwah yang disampaikan. Dakwah ekstrakurikuler menyoroti kepada peserta didik bahwa masyarakat adalah komunitas sosial yang cenderung mempersepsikan karakter dan kepribadian seseorang berdasarkan pola perilakunya sehari-hari. Dengan demikian, kepribadian spiritual dan keseharian siswa harus sesuai dengan standar sosial dan agama masyarakat. Pelatih mendorong kemampuan siswa untuk mengadopsi sikap-sikap dari Rofiq \& Nihayah (2018) sebagai berikut:

1) Berbudi pekerti luhur, yaitu memiliki sifat-sifat yang mencontohkan akhlak mulia dalam seluruh ajaran dan perbuatan Nabi Muhammad. Taqwa adalah ketaqwaan sejati ketika seseorang beriman dan mengikuti prinsip-prinsip Tuhan, mematuhi semua perintah-Nya, dan menjauhi semua yang dilarangNya. Kegiatan ekstrakurikuler ini menekankan pada akhlak mulia melalui kegiatan pembelajaran ekstrakurikuler seperti pengajian kelompok dan latihan dakwah yang sesuai dengan ketentuan pembelajaran.

2) Pengabdian. Maknanya, da'i adalah manusia yang senantiasa beribadah kepada Allah melalui gerak tubuh, perbuatan, dan ucapannya dimanapun dan kapanpun. Dan semua ibadahnya diarahkan dan dimaksudkan semata-mata untuk Allah, tanpa mengharapkan imbalan atau balasan. Dengan menonjolkan ciri tersebut, Pembina memastikan anak didiknya melakukan kegiatan ibadah secara disiplin dan tertib. Amalan ini dapat berbentuk doa kelompok atau pengajian.

3) Dapat diandalkan dan dapat diandalkan. Di Mis Nurul Iman, Pembina ekstrakurikuler menyoroti pentingnya integritas dan kejujuran sebagai sifat dasar kehormatan. Ciri-ciri utama seorang da'i adalah amanah (dapat dipercaya) dan shidq (jujur). Pendidikan karakter ditekankan melalui penyampaian materi dakwah kepada para da'i dan dosen agar mereka memiliki sikap amanah dan amanah yang tulus di lingkungan sosial.

4) Dalam contoh ini, kerendahan hati (Tawaduk) berarti bersikap sopan dalam masyarakat, tidak sombong, dan menahan diri dari menghina dan mengkritik orang lain. Pembina ekstrakurikuler di Mis Nurul Iman diharapkan rendah hati dan tidak sombong, guna memudahkan siswa dalam mengimplementasikan citacita ibadah Islam. Hal ini sesuai dengan penegasan Musrifah (2016) bahwa sikap rendah hati seorang da'i akan selalu dihormati oleh masyarakat.

5) Pembina kegiatan ekstrakurikuler sering menyoroti kemampuan bawaan anak-anak untuk menjadi individu yang unggul, kreatif, inovatif, dan memotivasi secara positif. Hal ini ditunjukkan melalui ceramah dan percakapan antar siswa yang mengikuti kegiatan ekstrakurikuler. Selain itu, siswa diintegrasikan untuk mengembangkan kepribadian yang berdisiplin dan berpengetahuan. Sifat kepribadian ini ditekankan karena siswa diharapkan untuk mematuhi konvensi agama dan masyarakat dan bertindak secara dewasa.

6) Bermartabat dan kharismatik, artinya anak-anak dalam ekstrakurikuler ini dikembangkan menjadi Da'i yang santun, berpikiran terbuka, dan menjauhi perilaku picik. Kewibawaan seorang da'i akan dipandang positif oleh peserta dakwah, sehingga memungkinkan terjadinya komunikasi yang efektif. Hal ini akan 
mengefisienkan distribusi materi dakwah, sehingga misi dakwah dapat terlaksana dengan lebih efisien. Pembina ekstrakurikuler membentuk perilaku ini dengan menekankan sifat otoritatif pemain mereka selama kuliah dan sesi belajar selama kegiatan ekstrakurikuler.

7) Pengetahuan yang cukup, khususnya pengetahuan tentang semua topik yang berkaitan dengan dakwah. Hal ini karena, untuk menyampaikan pesan dakwah secara akurat kepada mad', seorang da'i juga harus memiliki pengetahuan yang cukup tentang segala hal yang berkaitan dengan mad' pada tataran linguistik, tradisional, psikologis, budaya, dan emosional. Kegiatan ekstrakurikuler dakwah meliputi debat kelompok, kegiatan pelatihan dakwah, dan ceramah dari pelatih perorangan maupun kelompok.

8) Meningkatkan kemampuan komunikasi. Dakwah berperan dalam pembentukan karakter religius ini. Karena, pada intinya, dakwah adalah sarana penyampaian pesan-pesan kepada mad' untuk membujuk orang agar menganut prinsip-prinsip Islam. Komunikasi berhasil jika pesan dakwah ditangkap oleh mad' dan mudah dipahami jika disampaikan sesuai dengan cara pikir dan perasaan mad'. Alhasil, keterampilan komunikasi diasah melalui percakapan dan latihan dakwah bagi peserta ekstrakurikuler.

Menurut penuturan pelatih, banyak sikap yang dijadikan landasan pendidikan karakter anak-anak Mis Nurul Iman berdasarkan pendidikan yang diajarkan di ekstrakurikuler Da'i. Hal ini sesuai dengan pendapat Salim (2018) bahwa pembentukan karakter siswa yang religius merupakan proses dimana pelatih meningkatkan pemahaman siswa tentang peran dan fungsinya di lingkungan sosial sehingga siswa bertindak sesuai dengan etika lingkungan sosial dan akhlak mulia. kepribadian melalui pemahaman mereka tentang karakter religius. diri. Karakter religius siswa dapat membantu mengembangkan kepribadian yang memungkinkan mereka memahami posisi dan kelebihannya di lingkungan sosial. Pengembangan karakter religius juga dapat mengajarkan anak bahwa mereka harus berperilaku etis dan bermoral ketika berinteraksi dengan individu dan masyarakat lain. Hal ini menunjukkan bahwa semakin siswa mengembangkan mentalitas religius, semakin mereka mengembangkan rasa perilaku alami dan etis (Bintari et al., 2014).

Hal ini juga sesuai dengan pernyataan Ki Hadjar Dewantara bahwa tujuan pendidikan karakter religius adalah untuk mengembangkan kepribadian peserta didik yang merdeka dan mandiri, mempertimbangkan etika moral, memiliki keimanan yang kuat, bertakwa kepada Tuhan Yang Maha Esa, dan mengembangkan karakter peserta didik yang berakhlak mulia. berbudi luhur, cerdas, dan cerdas. Melalui pernyataan ini, penekanan ditempatkan pada pengembangan karakter religius siswa melalui mental kritis, serta pada pengembangan etika dan moral siswa agar dapat menyesuaikan diri dengan kehidupan sehari-hari di masyarakat dan di tingkat sekolah yang lebih tinggi (Hariandi \& Irawan, 2016). Dalam konteks ini, pendidikan karakter religius di Mis Nurul Iman terjalin untuk membentuk peserta didik menjadi pribadi yang bermoral yang tidak hanya berilmu tetapi juga bermoral dalam kehidupan sehari-hari. Seperti pada penelitian Shulhan (2020) menyebutkan bahwa pembiasaan prilaku bina lingukangan dan dapat membangun kesadaran tanggung jawab lingkungan.

Nilai religius tersebut juga berhubungan dengan Tuhan sebagai entitas yang menciptakan manusia di dunia. Perspektif guru tentang makna sebenarnya agama dalam pendidikan karakter adalah salah satu cara untuk menginternalisasi pendidikan karakter, karena menanamkan modal agama yang kuat pada siswa sejak usia dini. Dengan terus menerus menginternalisasi pendidikan karakter agama, landasan moral dan moral siswa akan lebih tahan terhadap pengaruh barang atau kejadian yang merugikan. Proses penanaman karakter dibagi menjadi tiga tahap: pengetahuan (knowing), pelaksanaan (doing), dan kebiasaan (habit) (Purandina \& Winaya, 2020).

Pendidikan ekstrakurikuler pada awalnya dilaksanakan di Mis Nurul Iman melalui pengenalan berbagai instrumen dasar yang menjadi pendorong dalam menjalankan Da'i, seperti sikap dasar da'i terhadap pengenalan materi-materi keagamaan yang akan dijadikan rumusan utama dalam melaksanakan Da'I (Sulistiyorini \& Nurfalah, 2019). Selain itu, peserta diarahkan untuk berpartisipasi dalam simulasi dakwah dan/atau kegiatan keagamaan lainnya untuk memastikan bahwa siswa tidak hanya menerima pengetahuan 
tentang bagian-bagian dakwah, tetapi juga memiliki keterampilan yang diperlukan untuk mempraktikkan prinsip-prinsip dakwah. Alat ini juga berkontribusi pada pembentukan karakter religius. Melalui simulasi dakwah, mahasiswa mengalami bagaimana menghayati sifat-sifat dakwah, yang meliputi kerendahan hati, ketaqwaan kepada Allah, serta kejujuran dan keluasan ilmu. Setelah simulasi dakwah, santri diinstruksikan untuk terus menunjukkan ciri-ciri tersebut guna mengembangkan kebiasaan (habits).

Jika kualitas karakter religius secara konsisten ditanamkan dan diterapkan dalam kehidupan nyata, siswa mengembangkan perilaku sosial yang ditanamkan etika, moral, kesopanan, kesopanan, dan kecerdasan dalam kehidupan sehari-hari, baik untuk kepentingan diri sendiri maupun orang lain. Karakteristik ini juga berkontribusi pada kesiapan siswa untuk menghadapi dinamika kehidupan sosial yang beragam, yang penuh dengan ketidakpastian. Pentingnya penanaman nilai karakter religius juga merupakan dampak dari penanaman nilai karakter religius terhadap kemampuan siswa untuk berhasil dalam kehidupan nyata dan situasi sosial. Hal ini sejalan dengan penelitian Mushfi et al. (2019) kegiatan ekstrakurikuler da'I yang berlandaskan "Panca Kesadaran dan Trilogi Santri" dapat menjadi tolak ukur pembangunan karakter yang menjadi pondasi utama. Menanamkan nilai karakter religius juga dapat melalui aktivitas sehari-hari (Oktari \& Kosasih, 2019). Sehingga akan berguna bagi keberlangsungan hidup untuk anak-anak dan kualitas dari kari karakter anakanak.

\section{KESIMPULAN}

Berdasarkan hasil penelitian, Mis Nurul Iman telah melakukan pembinaan atau pembinaan karakter bagi santri. Ada banyak aspek yang dikembangkan dalam pengembangan karakter dengan nilai-nilai agama yang ditekankan pada aspek jasmani dan rohani peserta ekstrakurikuler da'i, antara lain nilai-nilai agama yang berkaitan dengan bagaimana seseorang berpegang pada aspek spiritualnya, antara lain sifat ibadah, amanah, kerendahan hati, dan karakter. Selain itu, pendidikan karakter religius dilakukan melalui tahapan penanaman materi dalam pengetahuan (knowing), pelaksanaan (doing), dan pembiasaan (habit) melalui kegiatan pembekalan materi dan simulasi dakwah di ekstrakurikuler Dakwah Mis Nurul Iman. Siswa di Mis Nurul Iman memiliki kesempatan untuk mempelajari dasar-dasar karakter Islami dan menerapkannya dalam situasi dunia nyata melalui kegiatan ini.

\section{UCAPAN TERIMA KASIH}

Saya ucapkan terimakasih kepada Dr. Zaini Dahlan, M.Pd.I selaku dosen pembimbing yang telah membantu selama pengerjaan artikel jurnal, dan terima kasih juga kepada keluarga, dan teman-teman terdekat saya yang telah memberikan dukungan slama pengerjaan artikel jurnal.

\section{DAFTAR PUSTAKA}

Bintari, N. P., Dantes, N., \& Sulastri, M. (2014). Korelasi Konsep Diri Dan Sikap Religiusitas Terhadap Kecenderungan Perilaku Menyimpang Dikalangan Siswa Pada Kelas Xi Sma Negeri 4 Singaraja Tahun Ajaran 2013/2014. Jurnal Ilmiah Bimbingan Konseling, 2(1).

Fahlevi, R., Sari, R., \& Jannah, F. (2021). Kajian Pelaksanaan Pendidikan Karakter Di Sdn Sungai Jingah 6 Banjarmasin. Elementary School: Jurnal Pendidikan Dan Pembelajaran Ke-Sd-An, 8(1), 1-6. Https://Doi.Org/10.31316/Esjurnal.V8i1.865

Hambali, M., \& Yulianti, E. (2018). Ekstrakurikuler Keagamaan Terhadap Pembentukan Karakter Religius Peserta Didik Di Kota Majapahit. Pedagogik, 5(2), 193-208.

Hariandi, A., \& Irawan, Y. (2016). Peran Guru Dalam Penanaman Nilai Karakter Religius Di Lingkungan 
Sekolah Pada Siswa Sekolah Dasar. Jurnal Gentala Pendidikan Dasar, 1(1), 176-189. Https://Doi.Org/10.22437/Gentala.V1i1.7097

Hendra, T. (2018). Profesionalisme Dakwah Dalam Pemberdayaan Masyarakat. Jurnal At-Taghyir: Jurnal Dakwah Dan Pengembangan Masyarakat Desa, 1(1), 1-10. Https://Doi.Org/10.24952/Taghyir.V1i1.957

Hidayah, Y., Suyitno, Retansari, L., \& Ulfah, N. (2018). Pendidikan Karakter Religius Pada Sekolah Dasar: Sebuah Tinjuan Awal. Jurnal Iqra': Kajian Ilmu Pendidikan, 3(1), 329-344. Https://Journal.Iaimnumetrolampung.Ac.Id/Index.Php/Ji/Article/View/73

Huda, A. K., Montessori, M., Miaz, Y., \& Rifma. (2021). Pembinaan Karakter Disiplin Siswa Berbasis Nilai Religius Di Sekolah Dasar. Jurnal Basicedu, 5(5), 4190-4197.

Khairani, D., \& Putra, E. D. (2021). Analisis Implementasi Lima Nilai Karakter Pendidikan Pada Kegiatan Pembelajaran Di Sekolah Dasar. Jurnal Basicedu, 5(4), 2247-2255. Https://Doi.Org/10.31004/Basicedu.V5i4.1198

Mushfi, M., Iq, E., Fadilah, N., \& Jadid, U. N. (2019). Internalisasi Karakter Religius Di Sekolah Menengah Pertama Nurul Jadid. Jurnal Mudarrisuna, 9(1), 1-25.

Musrifah. (2016). Pendidikan Karakter Dalam Perspektif Islam. Edukasia Islamika, 1(1), 120-133. Https://Doi.Org/10.53649/Jutau.V14i01.309

Muthmainnah, A., Rahma, D., Robi'ah, F., \& Prihantini. (2022). Dampak Pandemi Covid-19 Terhadap Kegiatan Ektrskurikuler Di Sekolah Dasar Anti. Jurnal Basicedu, 6(1), 394-406.

Oktari, D. P., \& Kosasih, A. (2019). Pendidikan Karakter Religius Dan Mandiri Di Pesantren. Jurnal Pendidikan Ilmu Sosial, 28(1), 42. Https://Doi.Org/10.17509/Jpis.V28i1.14985

Perdima, F. E., \& Kristiawan, M. (2021). Nilai-Nilai Karakter Pada Permainan Tradisional Hadang Di Sekolah Dasar. Jurnal Basicedu, 5(6), 5342-5351.

Purandina, I. P. Y., \& Winaya, I. M. A. (2020). Pendidikan Karakter Di Lingkungan Keluarga Selama Pembelajaran Jarak Jauh Pada Masa Pandemi Covid-19. Cetta: Jurnal Ilmu Pendidikan, 3(2), 270-290. Https://Doi.Org/10.37329/Cetta.V3i2.454

Rahmawati, F., Afifulloh, M., \& Sulistiono, M. (2020). Budaya Religius: Implikasinya Dalam Meningkatkan Pendidikan Karakter Keagamaan Siswa Di Min Kota Malang. Elementeris: Jurnal Ilmiah Pendidikan Dasar Islam, 2(2), 21-35.

Rofiq, A., \& Nihayah, I. (2018). Komunikasi Sebagai Modal Utama Orang Tua Dalam Pembentukan Kepribadian Anak. 1-15. Https://Doi.Org/10.31219/Osf.Io/2cxyt

Salim, A. (2018). Peran Dan Fungsi Dai Dalam Perspektif Psikologi Dakwah. Al-Hikmah: Media Dakwah, Komunikasi, Sosial Dan Budaya, 8(1), 92-107. Https://Doi.Org/10.32505/Hikmah.V8i1.401

Sari, V. K., Akhwani, Hidayat, M. T., \& Rahayu, D. W. (2021). Implementasi Pendidikan Karakter Berbasis Nilai-Nilai Antikorupsi Melalui Ekstrakurikuler Dan Pembiasaan Di Sekolah Dasar. Jurnal Basicedu, 5(4), 2106-2115.

Shulhan. (2020). Pembentukan Moral Bina Lingkungan Bagi Peserta Didik Madrasah Ibtidaiyah. Jurnal Tarbiyah Al-Awlad, 10(2), 203-212.

Sulistiyorini, D., \& Nurfalah, Y. (2019). Pembentukan Karakter Religius Siswa Melalui Kegiatan Dewan Jama'ah Mushola (Djm) Di Smk Pgri 2 Kota Kediri. Indonesian Journal Of Islamic Education Studies (Ijies), 2(1), 40-49. Https://Doi.Org/10.33367/Ijies.V2i1.834 